\title{
CREATION OF ARMED FORCES IN NATO MEMBER STATES: PROMISING MODELS OF GERMANY AND NORWAY
}

\author{
Andrey V. Manoilo \\ Institute of Scientific Information on Social Sciences (INION) RAS, Moscow, Russian Federation
}

\section{Elena G. Ponomareva}

Moscow State Institute of International Relations (University) of the Ministry of Foreign Relations of the Russian Federation, Moscow, Russian Federation

\section{Philipp O. Trunov}

Institute of Scientific Information on Social Sciences (INION) RAS, Moscow, Russian Federation

\begin{abstract}
Introduction. One of the key tendencies of modern international development is the growing importance of the "factor of power". In this context, the initiated long process of the potential growth of the armed forces of the countries participating in NATO, which is of particular importance in the growth of new unconventional threats (one of the triggers of the Alliance transformation including through the strengthening of national units has become a global pandemic) is important from scientific and practical points of view. Methods and materials. The theoretical and methodological basis of the research is the theory of building armed forces. The basic sources for the analysis are official documents of military departments, as well as materials from related information centers, which reveal the parameters of the prospective appearance of the armed forces of the countries under study. NATO's statistical and summit reports also occupy a special place. Analysis. The goal of the article is the research of the armed forces building processes in Germany and Norway for the future until the mid-2030s. These case countries can show the tendencies of military development of NATO European member states in the whole taking into account the differences between Germany and Norway in terms of the geographical location, the population as the main human resource of the armed forces, as well as the transformation of leadership and dynamics of relations between the "historical West" and the Russian Federation, which allows us to characterize the overall trends in the military and political development of European NATO member states. Results. It is proved that the growth of military potential is based on two main groups of reasons. The first is due to the strategic deterioration of relations between the West and Russia since the mid-2010s. The second is that the armed forces of the European member States of NATO have reached the $\div$ "bottom" position in terms of almost all quantitative parameters. The continuing trend of decreasing numerical $\dot{\theta}$ indicators (people and technology) threatens to reduce the role of the state on the world stage. Therefore, it is * natural to see Germany's desire to become a "framework nation" in the recruitment of NATO rotation groups in Europe, as well as in the deployment of peacebuilding and peacekeeping missions outside the area of responsibility of the Alliance, which inevitably leads to a large-scale increase in the number of armed forces and the cost of their modernization. In the case of Norway the transformation of the armed forces occurs in the conditions of refusal to increase included human resources and enhance the value of the military presence of NATO partners (primarily the US) first of all in the process of reorganizing the national system of territorial defense. In both cases, there are still tendencies to transform the role of the US in Europe and to consolidate the confrontation with the Russian Federation.

Key words: military development, NATO, armed forces, Germany, Norway, perspective models.

Citation. Manoilo A.V., Ponomareva E.G., Trunov P.O. Creation of Armed Forces in NATO Member States: Promising Models of Germany and Norway. Vestnik Volgogradskogo gosudarstvennogo universiteta. Seriya 4. Istoriya. Regionovedenie. Mezhdunarodnye otnosheniya [Science Journal of Volgograd State University. History. Area Studies. International Relations], 2021, vol. 26, no. 1, pp. 67-81. (in Russian). DOI: https://doi.org/10.15688/ jvolsu4.2021.1.7
\end{abstract}




\title{
ПЕРСПЕКТИВНЫЕ МОДЕЛИ СТРОИТЕЛЬСТВА ВООРУЖЕННЫХ СИЛ СТРАН-ЧЛЕНОВ НАТО (НА ПРИМЕРЕ ГЕРМАНИИ И НОРВЕГИИ)
}

\author{
Андрей Викторович Манойло \\ Институт научной информации по общественным наукам РАН, г. Москва, Российская Федерация
}

\section{Елена Георгиевна Пономарева}

Московский государственный институт международных отношений (университет) МИД Российской Федерации, г. Москва, Российская Федерация

\section{Филипп Олегович Трунов}

Институт научной информации по общественным наукам РАН, г. Москва, Российская Федерация

Аннотация. Введение. Одной из тенденций современного мирополитического развития является увеличение фактора силы. В этой связи важным с научной и практической точек зрения является начавшийся длительный процесс роста потенциала вооруженных сил, относящихся к разным зонам ответственности стран-членов НАТО, приобретающий особое значение в условиях роста новых нетрадиционных угроз (одним из триггеров трансформации Альянса в том числе через усиление национальных единиц стала глобальная пандемия). Методы и материаль. Теоретико-методологической основой исследования стала теория строительства вооруженных сил, исследующая проблемы обоснования модернизации боевого состава, структуры, организации и комплектования армейских подразделений. Базовыми для анализа источниками стали официальные документы военных ведомств, а также материалы связанных с ними информационных центров, в которых раскрываются параметры перспективного облика вооруженных сил исследуемых стран. Особое место занимают также статистические отчеты и материалы программных для заявленной проблематики саммитов НАТО. Анализ. Задача статьи - исследование вопросов строительства вооруженных сил Германии и Норвегии на перспективу до середины 2030-х годов. Выбор кейсов определен географическим положением указанных стран, численностью населения как главного человеческого ресурса вооруженных сил, а также трансформацией лидерства внутри блока и динамикой отношений данных стран «исторического Запада» с РФ, что позволяет на их примере охарактеризовать в целом тенденции военно-политического развития европейских стран-членов НАТО. Результаты. Доказано, что в основе роста военного потенциала лежат две основные группы причин. Первая обусловлена стратегическим ухудшением отношений Запада и России с середины 2010-х гг, что является обоснованием выбора странами Альянса конкретных моделей строительства армий и флотов. Вторая заключается в достижении вооруженными силами европейских стран-членов НАТО положения «дна» с точки зрения практически всех количественных параметров. Сохранение тенденции сокращения численных (люди и техника) показателей грозит уменьшением роли государства на мировой арене. Поэтому закономерным видится стремление Германии к превращению в «рамочную нацию» при комплектовании ротационных группировок НАТО в Европе, равно и в развертывании миссий по миротворчеству и поддержанию мира за пределами зоны ответственности Альянса, что неизбежно ведет к масштабному увеличению численности вооруженных сил и затрат на их модернизацию. В случае Норвегии трансформация вооруженных сил происходит в условиях отказа от роста включенных людских ресурсов и усиления значения военного присугствия партнеров по НАТО (в первую очередь США), прежде всего, в процессе реорганизации национальной системы территориальной обороны. В том и другом случае сохраняются тенденции на трансформацию роли США в Европе и на закрепление конфронтации с РФ. Вклад авторов. А.В. Манойло обобщил и проанализировал информацию по развитию ВВС и сил специального назначения изучаемых стран на ближне- и среднесрочную перспективу, участвовал в оценке влияния фактора роботизации на развитие «военных машин» данных кейсов. Е.Г. Пономарева обосновала выбор методологии, а также Германии и Норвегии как фокусных стран для изучения, показав их значимость в системе обеспечения обороны и безопасности евро-атлантического сообщества. Ф.О. Трунов исследовал информацию по перспективам развития сухопутных войск и военно-морского флота ФРГ и королевства Норвегии, выделил критерии для сопоставления параметров их перспективного развития, а также выстроил модели последних.

Ключевые слова: военное развитие, НАТО, вооруженные силы, Германия, Норвегия, перспективные модели. 
Цитирование. Манойло А. В., Пономарева Е. Г., Трунов Ф. О. Перспективные модели строительства вооруженных сил стран-членов НАТО (на примере Германии и Норвегии) // Вестник Волгоградского государственного университета. Серия 4, История. Регионоведение. Международные отношения. - 2021. - Т. 26, № 1.- C. 67-81.-DOI: https://doi.org/10.15688/jvolsu4.2021.1.7

Введение. В условиях кризиса «существующего (или прежнего) миропорядка» [4, c. 32] и формирования «новой биполярности (США - КНР)» [2, с. 207] вновь возрастает значение фактора силы. При этом все большее практическое значение приобретают формы не непосредственного ее боевого использования, а демонстрации самой способности и готовности использования силового фактора. Параллельно увеличивается практическая ценность широкого спектра операций несилового характера, особенно по урегулированию вооруженных конфликтов и участия в преодолении вызовов нового порядка (пандемии, организация перемещения больших масс людей в критических ситуациях).

Показателен начавшийся во второй половине 2010-х гг. рост практически всех количественных характеристик вооруженных сил стран-участниц НАТО - причем в данном случае речь идет не только и не столько о США, сколько о европейском крыле блока. Уместно дать следующую периодизацию этого процесса. На первом этапе (2014 - первая половина 2015 г.) государства «исторического Запада» - в первую очередь входящие в Североатлантический альянс - достигли широкого консенсуса в вопросе принципиальной готовности наращивать свои военные потенциалы, что было закреплено на Уэльском саммите [31]. На следующем этапе (вторая половина 2015 - 2016 г.) обозначился ряд более конкретных характеристик данного процесса, особенно на ближайшую и среднесрочную перспективу, что нашло отражение в коммюнике Варшавского саммита (8-9 июля 2016 г.) [32; 34]. Наконец, на третьем этапе - с конца 2017 г. - на уровне национальных государств-членов блока стали приниматься документы по планированию строительства вооруженных сил с горизонтом до 15-20 лет. В этой связи данная статья представляет собой попытку выстроить модели перспективного военного строительства европейских стран-участниц НАТО на примере Германии и Норвегии.
Методы и материалы. Выбор конкретных кейсов для сравнительного анализа обусловлен их человеческим ресурсом (крупное и малое государство с точки зрения численности населения) и возможностями по развитию вооруженных сил, а также региональной принадлежностью (Центральная и Северная Европа), значимой геополитической ролью и дефакто возможностями влияния на принятие решений на уровне НАТО в целом. Так, Норвегия выступает «стержневым» государством-членом с точки зрения дислокации и наращивания потенциала группировки войск Альянса на его северном крыле - учитывая растущее внимание самого широкого круга государств к Арктике, значимость этого направления к началу 2020-х гг. резко возросла. Соответственно Королевство призвано контролировать границы зоны ответственности НАТО в северной части Европы. Показательно, что именно на территории Норвегии и ее прибрежных вод были проведены крупнейшие (с использованием свыше 50 тыс. личного состава) во второй половине 2010-х гг. учения HATO “Trident Jucnture 18" [28].

В свою очередь, Германия находится в глубине зоны ответственности НАТО, что делает интересным сопоставление подходов выбранных стран к строительству своих вооруженных сил. Эта характеристика резко отличает положение ФРГ в реалиях новой «холодной войны» от ситуации «классического» вида данного конфликта, когда Боннская республика располагалась на «передовой» противостояния Запада и Востока. Такая трансформация становится предпосылкой для широкого маневрирования официального Берлина в вопросах определения развития НАТО в целом и национальной «военной машины», глубоко интегрированной в Альянс [6, с. 87]. В частности, наиболее яркой иллюстрацией тому являются длительные существенные и притом носящие открытую форму при администрации Д. Трампа разночтения между США и ФРГ по определению объемов военных расходов, в том числе непосредственных ассиг- 


\section{ВООРУЖЕННЫЕ СИЛЫ И ВОЕННЫЕ ДЕЙСТВИЯ}

нований в бюджет Североатлантического альянса, а также по масштабу перспективного военного присутствия Соединенных Штатов в Германии [6, с. 90].

В данной связи следует подчеркнуть, что на рубеже 2010-х - начале 2020-х гг. политико-военным руководством ФРГ не вносилось существенных корректив в те планы по развитию вооруженных сил, которые созданы в 2017-2018 годах. Чем это обусловлено? Вопервых, высокой степенью преемственности внешней политики Германии, в том числе ее стратегической линии в области обеспечения обороны и безопасности. Планы по модернизации вооруженных сил являлись продуктом многолетней скрупулезной работы большой группы военных и гражданских экспертов соответственно, они не стали «эластичными» под давлением администрации Д. Трампа. Внесение существенных поправок в планы военного строительства, созданные в Норвегии и Германии в середине 2010-х гг., возможно к середине 2020-х гг. (2023-2024 гг.), когда хронологически закончится первый (в случае ФРГ) и основной (в случае Норвегии) этап модернизации и станет ясна полнота его выполнения, что позволит скорректировать дальнейшие планы.

Общим совпадающим знаменателем для планов ФРГ и требований 45-го президента США являлась приверженность росту военного потенциала Германии. Однако промежуточные и итоговые масштабы, скорость и целеполагание оказывались совершенно различны. Д. Трамп стремился к «разгрузке» США в военном отношении за счет ФРГ в Европе (прежде всего на различных направлениях в рамках деятельности НАТО). Обладая бизнес-мышлением, он стремился достичь лишь краткосрочной тактической выгоды (прежде всего в финансовом выражении, а также с точки зрения резервирования личного состава и техники), не осознавая, что «разгрузка» Германией Соединенных Штатов существенно укрепляет ее позиции на уровне евро-атлантической региональной подсистемы и в мире в целом во многом в ущерб самому Белому дому.

В этой связи, с точки зрения авторов, срез планов развития вооруженных сил является достаточно объективной характеристикой перспективного видения Германией и Норвегией своей политико-военной роли в Европе и мире. Соответственно, предпринятый на основе теории строительства вооруженных сил анализ моделей модернизации армий и флотов данных стран позволяет продолжить традиции отечественной школы [5] и существенно расширить ее эмпирическую базу.

Базовыми для анализа источниками стали официальные документы военных ведомств (вооруженных сил и министерств обороны Германии и Норвегии), а также материалы связанных с ними информационных центров, в которых раскрываются параметры перспективного облика вооруженных сил исследуемых стран. Преимуществом данных источников следует признать периодизацию этапов модернизации войск, а также определение части их конечных параметров (прежде всего применительно к сухопутным войскам) - однако, лишь с рубежа 2017-2018 гг. [10; 17]. Так, в Белой книге по политике в области безопасности и будущему бундесвера (опубликована в июле 2016 г.) даны лишь самые общие цели и наметки в области модернизации вооруженных сил Германии без их конкретизации [33] - к тому моменту определение окончательных параметров еще находилось на стадии, не подошедшей к завершению. Среди недостатков данной группы документов - слабое освещение эволюции организации внутренней структуры как имеющихся, как вновь формируемых соединений и частей с учетом факторов роботизации и отводимой им роли компонента многонациональных объединений и соединений. Отдельную группу источников представляют документы саммитов и статистические отчеты НАТО, в которых показана динамика военных расходов исследуемых кейсов. Традиционным недостатком данных материалов является изложение в них информации строго до момента опубликования, то есть отсутствуют прогнозы, что существенно облегчило конструирование перспективного облика вооруженных сил стран-участниц Североатлантического альянса.

Обзор литературы. Исследователями, в первую очередь на Западе, создан значительный задел в изучении широкого комплекса вопросов, включая военно-политические, взаимоотношений США как с европейскими партнерами в целом, так и отдельно взятыми 
странами, в том числе с ФРГ и в меньшей степени с Норвегией. Ряд авторов данных публикаций считают, что «шоковые» и во многом непредсказуемые с их точки зрения действия администрации Д. Трампа привели к возникновению состояния нестабильности внутри евро-атлантического сообщества, а не только вовне его: не случайным стало заявление Э. Макрона о «смерти мозга» Альянca [9, p. 18]. В связи с внутренней разбалансировкой блока видные германские исследователи К. Майор и П. Рудольф отмечают, что механизм саммитов НАТО (что показал пример подготовки проведенного в Брюсселе в 2018 г.) во многом теряет свою роль как площадки для выражения трансатлантической солидарности $[18 ; 20 ; 25]$. При этом на фоне неоднократно объявленного сокращения военного присутствия США в Европе наблюдается его возвратный рост, причем эта тенденция просматривается еще со времени президентства Б. Обамы. Параллельно европейские страны-участницы НАТО реализуют шаги, направленные на существенный рост потенциала Альянса (в том числе предоставляя новые войсковые контингенты в состав вновь создаваемых под его эгидой группировок). Интересен вопрос о мотивации этих действий. Официальный Берлин, подчеркивая свою инициативность, стремится увеличить собственную роль в решении вопросов обеспечения безопасности евро-атлантической региональной подсистемы в целом [19, S. 3], а отнюдь не только и не столько продемонстрировать лояльность США.

Одновременно осуществляется осмысление концептуальных документов национального и общего (НАТО и ЕС) уровней, посвященных вопросам перспективного военного строительства. Особое внимание в этой связи уделяется платформе PESCO, которая мыслится основой для существенного углубления и наращивания объемов военно-технической кооперации между странами-участницами Европейского союза. Эти исследования своим продолжением имеют проблематику обретения ЕС «стратегической автономии» в военно-политической сфере [8].

Нельзя не отметить, что заметное влияние на тенденции военного развития стран и институтов Запада оказывает динамика его отношений с Россией в условиях вступления их в фазу стратегического ухудшения. Среди массы работ, освещающих данную тематику, следует выделить коллективные монографии под руководством А. Торкунова, Н. Нунана, Т. Шаклеиной [27], а также под редакцией М. Александрова и О. Родионова [3].

Однако на этом фоне остаются существенные «белые пятна». Так, практически во всех исследованиях наблюдается отсутствие увязывания воедино более общих военно-политических сюжетов и конкретных планов по перспективному развитию различных родов войск и национальных «военных машин» в целом. Иными словами, в научном дискурсе отсутствует основополагающий вопрос: как запланированный перспективный облик вооруженных сил вписывается в политическую конъюнктуру евро-атлантического сообщества эпохи пост-Трампа? Попытку найти ответ на данный вопрос представляет собой данная статья. Для прогнозирования трендов военно-политического развития на перспективу целесообразно дать их краткую оценку в ретроспективном (со времени окончания «классической» холодной войны) и современном преломлении.

Анализ. Германия. В условиях реактуализации задач по обеспечению территориальной обороны, а также «усиления курса политико-экономической и военно-политической экспансии Запада (ЕС/США/НАТО) в ответ на кризис отношений с Россией» [1, с. 19] перед ФРГ в военно-политической сфере возникли две тесно связанные стратегические дилеммы. Первая - как распределить достаточно ограниченные численно ударные силы бундесвера для выполнения сразу двух крупномасштабных задач: стабилизации ситуации в конфликтогенных государствах вне зоны ответственности НАТО и обеспечения территориальной обороны вдоль ее периметра в Центральной и Северной Европе? Вторая как найти выход из противоречия необходимости наращивания военных усилий и длительной тенденции сокращения количественных параметров бундесвера?

Уместно дать более объемную картинку второй дилеммы. С одной стороны, бундесвер сумел создать «платформу» перспективных вооруженных сил, способных доста- 
точно успешно решать задачи как за пределами зоны ответственности Альянса, так и вдоль их периметра. Данная основа была создана в ходе первого, весьма продолжительного (1990-е - середина 2010-х гг.) этапа военной реформы. К числу войск «платформы» относятся в первую очередь 1-я танковая дивизия (1 тд) бундесвера (в составе 9-й учебной танковой, 21-й танковой и 41-й мотопехотной бригад, а также интегрированной в состав 1 тд 43-й нидерландской механизированной бригады) [23], дивизия сил быстрого реагирования (в составе 1-й аэромобильной бригады, полков транспортной авиации и 11-й нидерландской бригады) в сухопутных войсках [12] и 2-я оперативная флотилия бундесмарине [13]. Люфтваффе в данном отношении находится в отстающем положении. С другой стороны, как уже отмечалось, это достижение бундесвером «дна» с точки зрения количественных параметров.

В 2017-2018 гг. Министерство обороны ФРГ определило контуры путей выхода из данных дилемм. С 2019 г. начался второй этап военной реформы - он должен проходить по формуле « +++ +» (то есть параллельный рост общего назначения, кризисного реагирования и общий) и состоять, согласно замыслу германского политико-военного руководства, из трех основных фаз.

В ходе первой (2019-2023 гг.) повышенное внимание уделяется росту возможностей ФРГ в деле комплектования бригады сверхповышенной боевой готовности (Very High Readiness Joint Task Force brigade, VJTF) [10]. Бундесвер должен обрести возможность комплектовать не только штаб и сухопутную (как это было, в частности, в ходе учений НАТО «Trident Juncture 18» в Норвегии [28]) компоненту VJTF, но и остальные - военно-морскую, военно-воздушную, сил специальных операций [10]. Тем самым Германия стремится продемонстрировать практическую возможность полностью комплектовать «острие копья» (соединение VJTF) ударной группировки войск НАТО (силы быстрого реагирования Альянса), расположенной во втором стратегическом эшелоне.

Кроме того, уже в ходе первой фазы люфтваффе должна обрести способность самостоятельно полностью обеспечивать с воз- духа развертывание и действия группировок с ведущим участием наземных войск ФРГ [10]. Из соединений бундесмарине основное внимание будет уделено повышению возможностей 2-й оперативной флотилии, предназначенной для обеспечения военного присутствия в Мировом океане.

В ходе второй фазы (2024-2027 гг.) бундесвер должен достичь возможности играть роль «рамочной нации» в деле комплектования группировок сил общего назначения, то есть предназначенных для обеспечения территориальной обороны в Европе. Это означает способность комплектовать «ядро» сил не только быстрого реагирования, но и передового развертывания (СПР) НАТО. Для этого в составе сухопутных войск к 2026 г. должна быть создана новая дивизия в составе трех «тяжелых» (то есть танковых и мотопехотных) бригад численностью до 20 тыс. военнослужащих [10]. Она будет формироваться на базе 1-й танковой дивизии. Наиболее вероятен следующий сценарий: каждая часть 1 тд (на уровне бригады и ниже) выделит до 50 \% своего личного состава для вновь формируемых частей новой дивизии, взамен получая новобранцев. Таким образом созданное соединение должно стать «осевым» в процессе развертывания СПР, позволяя на ротационной основе держать в их составе в Восточной Европе не менее одной «тяжелой» бригады - то есть, как минимум, столько же войск, сколько имеют США в регионе в реалиях второй половины 2010-х годов. С нашей точки зрения, это является иллюстрацией стремления ФРГ играть сопоставимую с Соединенными Штатами военную роль в НАТО в Европе, хотя мы прекрасно понимаем, что путь от поставленной цели до ее практической реализации может быть долгим и трудным.

График роста численности бундесвера определен лишь до 2025 г. - к этому времени он должен иметь в своем составе 203 тыс. военнослужащих (+ 25 тыс. к минимальному уровню середины 2010-х гг. - табл. 2) [29]. По мнению авторов, Министерство обороны ФРГ не стремится «заглядывать за этот горизонт», желая сначала удостовериться в эффективности мер по увеличению жалованья в бундесвере (особенно на рядовых и унтерофицерских должностях). С одной стороны, на 
фоне последствий мирового экономического кризиса (помноженного на существенные проблемы в ЕС и зоне евро), обострившихся в результате пандемии коронавируса 2020 г., приток добровольцев-контрактников может усилиться (военное ведомство гарантирует не только регулярный доход, но и целый ряд социальных преференций). С другой - после столь длительной нисходящей динамики численности бундесвера и резкого уменьшения положительного восприятия военной службы со стороны общества представленные выше аргументы могут «не сработать». В этом случае возможны два сценария: более «мягкий» (дальнейший, существенно опережающий средний по ФРГ рост жалования военнослужащих) и «жесткий»- возвращение к всеобщей воинской повинности, которая снижает финансовые издержки бундесвера и обеспечивает частичную занятость. Последний сценарий нам кажется маловероятным, поскольку даже его декларация может привести к «торпедированию» планов военного ведомства со стороны оппозиции и общественности. Поэтому, если подобное решение и будет принято, то оно станет отложенным.

Сложность прогнозирования роста численности бундесвера на долгосрочную перспективу обусловлена неопределенностью и теми параметрами, на которые он должен выйти в ходе третьей фазы (2028-2031). Так, в составе сухопутных войск будут созданы еще две дивизии и пять - семь новых бригад. С высокой долей вероятности, одна из вновь созданных дивизий станет «тяжелой» (также будет формироваться на базе 1 тд) и будет выполнять задачи в составе сил быстрого реагирования (СБР) и сил передового развертывания (СПР) НАТО в Европе. Другая станет развертываться на базе дивизии СБР, предназначенной для выполнения задач за пределами зоны ответственности Альянса. При этом следует учитывать, что дивизия СБР образца 2019 г. имеет всего одну (11-ю аэромобильную, не считая 1-й нидерландской) бригаду [12]. Скорее всего, ей будет передана еще одна. Соответственно, это обеспечит возможность для ФРГ играть роль «рамочной нации» при комплектовании группировок под эгидой Альянса и ЕС широкого функционального спектра как внутри зоны ответственности НАТО, так и за ее пределами, что подчеркивается в качестве целеполагания планируемых военных преобразований [10].

В случае нехватки личного состава «тяжелые» дивизии (суммарно четыре соединения, в том числе два вновь созданных), предназначенные для использования под эгидой НАТО в Европе, останутся трехбригадного состава, а «легкие», предназначенные для использования вне зоны ответственности блока, - одно- или двухбригадными. В ходе третьей фазы бундесмарине (в первую очередь 2-я оперативная флотилия) должна обладать возможностью постоянно держать в море группировку в 15 надводных кораблей и ПЛ.

Таким образом, если в ходе первых двух фаз (до 2027 г. включительно) основное внимание будет сосредоточено на воссоздании войск для территориальной обороны (при сохранении имеющихся СКР), то на третьей планируется уже параллельное развитие обеих составляющих бундесвера.

Отличительной чертой всех соединений и частей бундесвера - как вновь создаваемых, так и реорганизуемых - является превращение их в межвидовые [21], то есть происходит увеличение доли непрофильных войск. Так, в составе танковых и мотопехотных войск будут увеличены парки армейской авиации (особенно численность и состав команд разведывательных БПЛА), силы специальных операций; будут созданы подразделения киберзащиты и при необходимости - морская компонента. Это существенно повысит боевые возможности одной отдельно взятой части (соединения). Главное целеполагание этого - стремление придать соединениям и частям возможность стать «ядром» многонациональных группировок под эгидой НАТО и ЕС как в пределах зоны ответственности Альянca, так и вне ее, то есть опять же речь идет о потенциальном закреплении за ФРГ роли «рамочной нации».

Из всех родов войск наиболее детализованные и масштабные планы усиления составлены для сухопутных сил. Чем это обусловлено? С одной стороны, именно наземные войска - бундесхеер - подверглись наиболее масштабным сокращениям с 1990-х гг. исходя из того, что именно эти формирования (с учетом продолжительности и затратности 


\section{ВООРУЖЕННЫЕ СИЛЫ И ВОЕННЫЕ ДЕЙСТВИЯ}

подготовки одного отдельно взятого военнослужащего) будет проще и быстрее наращивать, чем люфтваффе или кригсмарине. С другой - именно наземные подразделения составляли основную массу (до 80 \% и более) контингентов практически во всех заграничных миссиях бундесвера [26]. Соответственно они не только накопили богатый опыт, но доказали свою роль как «станового хребта» вооруженных сил ФРГ. Общее количество бригад в сухопутных войсках возрастет с семи в 2019 г. (не считая компоненты германо-французской бригады) до 15-17, а дивизий - с трех до шести. Особое внимание в планах военного ведомства отводится формированию артиллерийских батальонов с крупнокалиберной артиллерией (особенно в интересах «тяжелых» дивизий) [10].

Согласно расчетам авторского коллектива, увеличится не только численность сухопутных войск (с отметки в 60 тыс. в 2018 г. до 110-125 тыс. к 2032 г.), но и их удельный вес (до 40-45 \%) в составе вооруженных сил в целом. Бундесхеер ждет не только количественный рост парка вооружений и военной техники, особенно тяжелой, но и ее качественное обновление. Во-первых, планируются закупки больших партий пилотируемой тяжелой бронетехники (различных модификаций «Leopard 2», БТР «Boxer», БМП «Рuma»), а также разрабатываемых совместно с Францией новых видов тяжелых артиллерийских систем. Так, количество танков, согласно расчетам авторов, должно увеличиться с 900 (2019 г.) [14] до 2-2,5 тыс. единиц. Это будет происходить как за счет закупок новых машин, так и путем расконсервации поставленных на хранение в 1990-е - начале 2000-х годов.

Во-вторых, ожидаются высокие темпы роста насыщения сухопутных сил ФРГ автоматизированными системами. Интересно, что по данным официального сайта Бундесвера (http://www.deutschesheer.de) к 2019 г. при общей численности парка беспилотных летательных аппаратов более чем в 700 единиц, свыше $95 \%$ из них было сосредоточено в сухопутных войсках (!), а отнюдь не ВВС.

Чем обусловливалась эта парадоксальная на первый взгляд ситуация? Как уже отмечалось, именно сухопутные войска (части 1 тд и дивизии СБР) составляли основу загра- ничных миссий бундесвера. С учетом характера выполняемых ими задач (преимущественно небоевых) этим войскам в целом не требовалась поддержка собственно боевой авиации, при этом ощущалась острая и постоянная нужда в транспортной и разведывательной авиации. В этой связи вариант временных переподчинений последней из состава люфтваффе отпадал. Был избран другой путь - создания мощной разведывательной и транспортной (во втором случае - пилотируемой) армейской авиации.

На этом фоне особое значение приобретает вопрос финансирования. Германия во второй половине 2010-х гг. тратила на военные цели лишь порядка 1,2 \% от своего ВВП, что администрация Д. Трампа последовательно ставит в вину ФРГ [16]. Однако попытки монетаризации отношений не принесли ожидаемого эффекта - Германия не собирается менять заложенной скорости наращивания своего военного потенциала. К середине 2020-х гг. доля военных затрат от ВВП составит лишь 1,5 \% и продолжит медленно увеличиваться в дальнейшем. В абсолютном выражении к 2025 г. этот показатель составит 58-60 млрд евро [21], что вполне позволит обеспечить глубокую модернизацию бундесвера. Германия обладает мощной развитой военной промышленностью, переходящей к технологическому укладу «Индустрия 4.0» (основана на роботизации производственных цепочек). Это позволит существенно удешевить выпуск военной продукции. В этой связи следует отметить и существенный научно-технологический задел ФРГ в области разработки собственных беспилотников (особенно малогабаритных). В 2017 г. в составе бундесвера было создано новое межвидовое киберкомандование, ответственное за стабильную работу автоматических систем управления, навигации, связи и разведки.

Согласно расчетам авторов, общая численность бундесвера к началу 2030-х гг. будет колебаться в диапазоне от 240 до 280 тыс. военнослужащих (то есть быть в 1,3-1,7 раза больше нынешней). В количественном плане это уровень середины 2000-х гг, однако в качественном, особенно с учетом используемого опыта, реорганизации и технологических инноваций - существенно больше. Соответ- 
ственно к 2032 г. ФРГ должна обладать полноценными возможностями играть роль «рамочной нации» (то есть предоставлять не менее $40 \%$ от общей численности личного состава и единиц техники и управлять) в комплектовании группировок стран-участниц НАТО и ЕС как в Европе, так и при развертывании миссий за пределами континента. Дефакто это должно привести к серьезному усилению конкуренции между ФРГ и США, особенно в военно-политической сфере. Де-факто шаги администрации Д. Трампа, настаивающего на росте всех военных (и особенно финансовых) усилий ФРГ для «разгрузки» США в Европе, дадут неожиданный для официального Вашингтона эффект - идя по этому пути, Германия может поставить под сомнение лидерство Соединенных Штатов на континенте в столь чувствительной сфере, как военно-политическая. Примечательно, что в отличие от 1 тд, 10-й танковой дивизии, чьи войска должны образовывать совместную с контингентами США на территории ФРГ группировку, отводится в перспективном военном планировании вспомогательная роль. При этом Белый дом, вопреки более ранним выступлениям Трампа, заявил об увеличении своего военного присутствия в Германии на 1,5 тыс. военнослужащих к 2020 г., то есть до 35 тыс. [30], хотя ФРГ не демонстрировала заинтересованности в этом.

В Норвегии качественно новый этап строительства вооруженных сил стартовал в 2015 г. и был направлен на реализацию двух основных задач в средне- и долгосрочной перспективе:

1) наращивание возможностей по обеспечению территориальной обороны, в том числе северных губерний страны (Финнмарк, Тромс, Нурланд);

2) увеличение сил кризисного реагирования (СКР), способных оперировать не только в прибрежных, но и отдаленных акваториях и на островах Северного Ледовитого океана (СЛО) [7, с. 22].

Для Норвегии, безусловно, более перспективной является вторая задача. Это обусловлено как экономическими выгодами - расширение доступа к ресурсам бассейна СЛО, в том числе энергетическим и биологическим, так и политическими - в первую очередь ук- реплением позиций как арктической державы на фоне небольшого удельного веса в международной системе в целом. При этом, в отличие от Германии, для которой направления использования войск в интересах территориальной обороны (в Европе) и СКР (в основном в Азии и Африке) весьма различаются, Норвегия обладает возможностью комплексного решения обеих задач вследствие своего географического положения. Именно в северных губерниях сосредоточены основные пункты базирования и материально-технического снабжения войск, предназначенных к использованию в СЛО.

Основная нагрузка в деле обеспечения территориальной обороны ложится на сухопутные войска и ВМС, а по присутствию в СЛО ВМС, ВВС и ССО. К середине 2020-х гг. в случае военно-морских сил основное внимание будет сфокусировано:

- на использовании фрегатов (с вертолетами на борту) как наиболее приспособленных военных судах для обеспечения присутствия в удаленных акваториях СЛО. Предполагается постепенное обновление парка фрегатов (три новых вместо такого же числа списываемых к 2021 г.), а также укомплектование всех их личным составом на $100 \%$ [22, p. 13];

- силах охраны побережья, особенно кораблей внешней береговой стражи (в том числе как возможной поддержки фрегатов в случае необходимости) и морской пехоты, то есть войск многопрофильного назначения (см. табл. 1-2).

Однако в целом число боевых единиц ВМС Норвегии не только не увеличится, но, напротив, уменьшится за счет списания целых «нефокусных» классов кораблей (корветов) и нулевого роста количества большинства остальных. Для дизельных ПЛ предусмотрено два сценария: как полного списания (!), так и продления срока службы [22, p. 22].

Аналогичные тенденции наблюдаются и при формировании перспективного облика военно-воздушных сил. Так, число истребителей F-35 сократится к середине 2020-х гг. на $25 \%$ (с 52 до 42 самолетов), но при условии обновления их парка самолетами V поколения. Планируется, что именно эта статья станет основной в военном бюджете Норвегии в 2019-2023 годах. Развитие вертолетного пар- 


\section{Таблица 1. Изменение состава ВМС для оперирования в удаленных акваториях}

Table 1. Changes in the composition of the Navy for operating in remote waters

\begin{tabular}{|c|c|c|c|c|c|}
\hline $\begin{array}{c}\text { Класс } \\
\text { кораблей }\end{array}$ & $\begin{array}{c}\text { Фрегаты } \\
\text { (+ вертолеты на борту) }\end{array}$ & Корветы & $\begin{array}{c}\text { Дизельные } \\
\text { ПЛ }\end{array}$ & $\begin{array}{c}\text { Контрминные } \\
\text { группы }\end{array}$ & $\begin{array}{c}\text { Вспомогательные суда } \\
\text { (в том числе транспорты) }\end{array}$ \\
\hline 2015 & $5(+6)$ & 6 & 4 & 3 & $3(1)$ \\
\hline 2024 & $5(+6)$ & - & $-(4)$ & 5 & $3(1)$ \\
\hline
\end{tabular}

Примечание. Составлено по: [22, p. 15;25].

\section{Таблица 2. Изменение состава ВМС прибрежной обороны}

\section{Table 2. Changes in the composition of the Coastal Defense Navy}

\begin{tabular}{|c|c|c|c|c|}
\hline Категория & $\begin{array}{c}\text { Корабли внешней береговой } \\
\text { стражи (+ вертолеты поддержки) }\end{array}$ & $\begin{array}{c}\text { Команды бере- } \\
\text { говой охраны }\end{array}$ & $\begin{array}{c}\text { Корабли внутренней } \\
\text { береговой стражи }\end{array}$ & $\begin{array}{c}\text { Команды } \\
\text { морской пехоты }\end{array}$ \\
\hline 2015 & $4(-)$ & 4 & 5 & 2 \\
\hline 2024 & $8(+8)$ & 4 & 5 & 4 \\
\hline
\end{tabular}

Примечание. Составлено по: [22, p. 15;25].

ка ВС страны характеризуется в основном нулевым (в частности, для спасательных) или отрицательным ростом [22, p. $15 ; 25]$.

Сухопутные войска Норвегии подвергнутся глубокой реорганизации, также сопровождаемой сокращениями. Во-первых, будет упразднено управление бригады «Север» (в нее входили все регулярные части, сосредоточенные в северных провинциях, или $2 / 3$ от всей сухопутный армии). Вкупе с сокращением числа «тяжелых» батальонов («2+1» (разведывательный) к 2025 г. вместо «4 + 1» в 2015 г.) [22, p. 15; 25] в армии это повысит самостоятельность и тактико-оперативную нагрузку каждого из них. Роста возможностей каждого батальона планируется достичь за счет увеличения числа единиц тяжелой техники (особенно ОБТ) и особенно парка полевой артиллерии (в том числе дальнобойной), а также более тесного интегрирования с другими родами войск Королевства и контингентов государств-партнеров [22, р. 12-22]. Редукциям подвергнется и королевская гвардия - вместо батальона будет оставлена лишь его «рамочная основа» [22, p. 13]. В составе сил спещиальных операций (CCO) должен быть увеличен каждый из трех имеющихся отрядов, а также вновь созданы два резервных [22, p. 14]. Де-факто ССО продолжат играть роль мобильного резерва (располагая собственной транспортной авиацией в первую очередь вертолетами), которые могут одновременно поддерживать как силы территориальной обороны, так и кризисного реагирования.
Чем обусловлены данные долгосрочные тенденции, особенно редукции внутри родов вооруженных сил? Королевство вплотную подошло к «потолку» роста всех ключевых военных показателей при условии сохранения имеющейся модели развития. Так, суммарно от всей численности населения страны (5,28 млн) действующие вооруженные силы (20-21 тыс.) составляют $0,4 \%$, а с учетом резервистов (30 тыс.) - примерно $1 \%$, что является высоким показателем для евро-атлантического сообщества. Норвегия занимает в НАТО второе место после США (!) по объему военных расходов на одного жителя почти 1,5 тыс. долларов (см. табл. 3).

Имея столь высокие показатели, Норвегии намного сложнее, чем Германии, наращивать как численность вооруженных сил, так и расходы на оборону. Пересмотр этого положения будет означать отказ (как минимум частичный) от модели государства «всеобщего благоденствия», к чему, как показывает направленность планов долгосрочного военного строительства, норвежское военно-политическое руководство не готово. Единственная возможность реализации данного сценария - это возникновение мощного «стратегического шока» для безопасности Норвегии.

В этой связи Королевство выбрало путь реализации нелинейных решений по существенному увеличению собственного военного потенциала:

- выстраивание системы «всеобщей обороны» (Total Defence), концепция которой основывается на активной поддержке граждан- 


\section{Таблииа 3. Ключевые военные показатели Норвегии}

Table 3. Key military indicators of Norway

\begin{tabular}{|l|c|c|c|c|c|c|c|c|}
\hline \multicolumn{1}{|c|}{ Показатель } & 2011 г. & 2012 г. & 2013 г. & 2014 г. & 2015 г. & 2016 г. & 2017 г. & 2018 г. \\
\hline $\begin{array}{l}\text { Общие военные расходы (в текущих } \\
\text { ценах), млн долл. }\end{array}$ & 7,232 & 7,143 & 7,407 & 7,337 & 5,816 & 6,064 & 6,463 & 7,266 \\
\hline $\begin{array}{l}\text { Общие военные расходы (в ценах } \\
\text { 2010 г.), млн долл. }\end{array}$ & 6,530 & 6,556 & 6,659 & 6,947 & 6,833 & 7,281 & 7,458 & 7,890 \\
\hline Доля расходов на оборону, \% & 1,51 & 1,47 & 1,48 & 1,51 & 1,46 & 1,54 & 1,55 & 1,61 \\
\hline Прирост расходов на оборону, \% & $+0,47$ & $+0,40$ & $+1,57$ & $+4,32$ & $-1,63$ & $+6,55$ & $+2,43$ & $+5,79$ \\
\hline $\begin{array}{l}\text { Военные расходы на душу } \\
\text { населения, долл. }\end{array} 1318$ & 1306 & 1311 & 1352 & 1316 & 1391 & 1413 & 1483 \\
\hline Численность личного состава & 21 & 21 & 20 & 21 & 21 & 20 & 20 & 20 \\
\hline Структура военных расходов (100\%) \%) & \multicolumn{7}{|l|}{} \\
\hline Разработка и закупка ВиВТ, \% & 17,04 & 17,76 & 18,89 & 21,17 & 22,49 & 24,05 & 24,70 & 26,77 \\
\hline Содержание личного состава, \% & 43,43 & 42,38 & 41,02 & 39,36 & 38,70 & 37,28 & 36,10 & 34,32 \\
\hline Развитие военной инфраструктры, \% & 4,22 & 4,86 & 5,64 & 6,00 & 5,60 & 6,96 & 7,35 & 7,97 \\
\hline Другие статьи, \% & 35,31 & 35,00 & 34,45 & 33,46 & 33,21 & 31,71 & 31,84 & 30,94 \\
\hline
\end{tabular}

Примечание. Составлено по: [11, p. 5-11].

ским обществом и институциями вооруженных сил, особенно в случае возникновения военно-политического кризиса;

- обеспечение развертывания военного присутствия государств-партнеров в следующих основных формах: ротационном (с трансформацией в постоянное на перспективу) и оперативного получения масштабной помощи посредством использования отлаженных военно-логистических цепочек. Первая форма реализуется США, вторая - ФРГ. Так, на территории Финнмарка дислоцированы подразделения Корпуса морской пехоты США, численность которых в 2018 г. была увеличена с 330 до 700 военнослужащих [15]. В ходе учений «Trident Juncture 2018» была отработана переброска крупной группировки бундесвера (8,8 тыс. военнослужащих и четыре тысячи (!) единиц боевой и вспомогательной техники) на территорию Королевства [7, с. 21-22; 28], то есть выстроена двусторонняя военно-логистическая цепочка. В период «классической» холодной войны в Норвегии отсутствовали контингенты государств-партнеров по НАТО, что указывает на растущую значимость Королевства в системе военного планирования евроатлантического сообщества в целом.

Результаты. Специфика развития Альянса, «сохраняющего потенциал нестабильности» [24, p. 159], показывает, что из трех обозначенных в начале статьи факторов - достижение «дна» количественных параметров вооруженными силами европейских стран-уча- стниц НАТО; стратегического ухудшения отношений Запада с РФ и глубокой трансформации роли США (от лидерства - к гегемонии) в евро-атлантическом сообществе - первый является константой при любом развитии событий. Два других расположим по осям координат, что формирует четыре сценария (см. рисунок).

Трансформация вооруженных сил Германии соответствует координатам полей II и III (последнего - особенно после 2027 г.). Менее выгодны для ФРГ сценарии IV и особенно I переход США к гегемонии станет серьезным препятствием на пути реализации лидерских амбиций Германии внутри евро-атлантической региональной подсистемы (в том числе как «рамочной нации» группировок НАТО в Европе), равно как и на мировом уровне. При этом бундесвер являет собой пример единственных (из всех рассмотренных) вооруженных сил, способных к 2030-м гг. успешно использоваться при любом из сценариев без изменения заданного вектора перспективного строительства.

Исходя из заложенной схемы развития вооруженных сил Норвегии, ей наиболее выгодны сценарии II, I, а также IV. При любом из них королевство получает возможность опираться на помощь партнеров по НАТО для решения актуальных задач внешней политики в акватории СЛО. Менее выгоден официальному Осло сценарий III, ибо он потребует резкого наращивания собственных усилий 


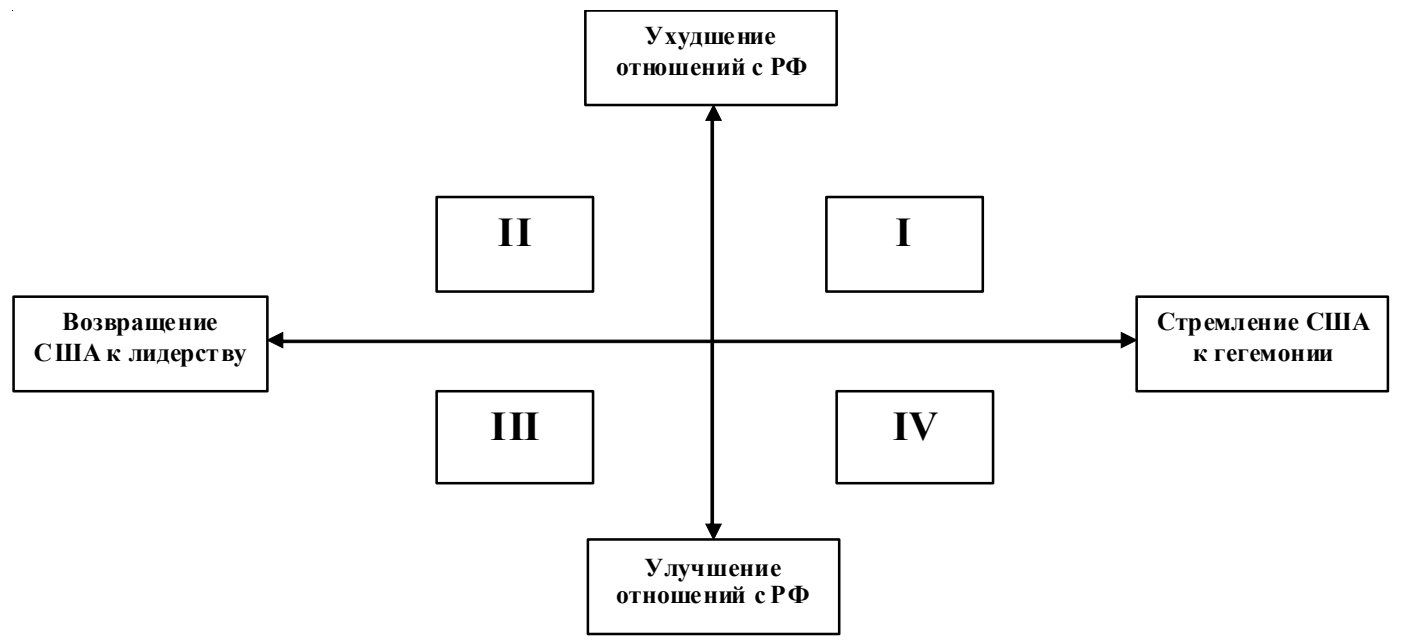

Сценарии развития отношений Запад - Россия

Scenarios for the development of West-Russia relations

(вследствие уменьшения поддержки по линии партнеров НАТО) и перенаправления части усилий на географически весьма удаленные направления.

\section{СПИСОК ЛИТЕРАТУРЫ}

1. Данилов, Д. А. Глобальная стратегия ЕС: восточный вектор / Д. А. Данилов // Современная Европа. - 2017. - № 1 (73). - C. 10-21. - DOI: http:// dx.doi.org/10.15211/soveurope120171021.

2. Дегтярёв, Д. А. Оценка современной расстановки сил на международной арене и формирование многополярного мира / Д. А. Дегтярёв. М. : РУСАЙНС, 2020. - 214 c.

3. Мир в XXI веке: прогноз развития международной обстановки по странам и регионам / под ред. М. В. Александрова, О. Е. Родионова. - М. : МГИМО-Университет, 2018. - 768 с.

4. Никитин, А. И. Современный миропорядок: его кризис и перспективы / А. И. Никитин // Полис. Политические исследования. - 2018. № 6. -С. 32-46. - DOI: 10.17967/jpps/2018.06.03.

5. Останков, В. И. Успешное решение проблем строительства Вооруженных Сил - важнейшее условие обеспечения национальной безопасности / В. И. Останков // Военная безопасность Российской Федерации в XXI веке : сб. науч. ст. / ред. генерал-полковника Ю. Н. Балуевского. - М. : ЦВСИ, 2004. - C. 210-226.

6. Трунов, Ф. О. Изменение роли ФРГ в Европе и мире в реалиях новой холодной войны: политико-военное измерение / Ф. О. Трунов // Актуальные проблемы Европы. - 2020. - № 1 (105). - С. 85109. -DOI: 10.31249/ape/2020.01.05.
7. Трунов, Ф. О. Роль Норвегии в военном планировании НАТО на современном этапе / Ф. О. Трунов // Европейская безопасность: события, оценки, прогнозы. -2020. - № 56 (72). - С. 20-23.

8. Beer, J. Machen 34 Projekte die EU verteidigungsfähig? - Electronic text data. - Mode of acceess: https://www.faz.net/aktuell/politik/ausland/ pesco-machen-34-projekte-die-eu-verteidigungsfae hig-16083341.html (date of access: 25.05.2020). - Title from screen.

9. Briefing Macron's view of the world // The Economist. - 2019. - 9 Nov. - P. 17-20.

10. Bundeswehr-Pläne: Heer soll drei neue Divisionen bekommen. - Electronic text data. - Mode of access: https:/www.dbwv.de/aktuelle-themen/ politik-verband/beitrag/news/bundeswehr-plaeneheer-soll-drei-volle-divisionen-bekommen/ (date of access: 25.07 .2020$)$. - Title from screen.

11. Defence Expenditures of NATO Countries (2011-2018). - Electronic text data. - Mode of access: https://www.nato.int/nato_static_fl2014/assets/pdf/ pdf_2018_07/20180709_180710-pr2018-91-en-pdf(date of access: 25.07 .2020$)$. - Title from screen.

12. Division Schnelle Kräfte. - Electronic text data. - Mode of access: https://www.bundeswehr.de/ de/organisation/heer/organisation/division-schnellekraefte (date of access: 25.07.2020). - Title from screen.

13. Einsatzflottille 2. - Electronic text data. Mode of access: https:/www.bundeswehr.de/de/ organisation/marine/organisation/einsatzflottille-2 (date of access: 25.07.2020). - Title from screen.

14. German military strength. - Electronic text data. Mode of access: https://www.globalfire power.com/ country-military-strength-detail.asp? country_id=germany (date of access: 25.07.2020). - Title from screen.

15. Gotkowska, J. US Marines in northern Norway/ J. Gotkowska. - Electronic text data. - Mode 
of access: https://www.osw.waw.pl/en/publikacje/ analyses/2018-06-20/us-marines-nothern-norway-0 (date of access: 25.07.2020). - Title from screen.

16. Joint Press Conference with President Trump and German Chancellor Merkel. - Electronic text data. Mode of access: https://www.whitehouse.gov/ briefings-statements/joint-press-conferencepresident-trump-german-chancellor-merkel/ (date of access: 25.07 .2020$)$. - Title from screen.

17. Konzeption der Bundeswehr, 2018. - Berlin : Bundesministerium der Verteidigung, 2018. - $42 \mathrm{~s}$.

18. Major, C. Beyond the NATO Summit: Why There Is Long-Term Transatlantic Trouble Ahead / C. Major. - Electronic text data. - Mode of access: http://atlantic-community.org/beyond-the-natosummit/ (date of access: 25.07.2020). - Title from screen.

19. Major, C. Die Rolle der NATO für Europas Verteidigung/C. Major. - Berlin : Stiftung Wissenschaft und Politik, 2019. - 42 s.

20. Major, C. Ein schwieriger Gipfel für die NATO / C. Major // SWP-Aktuell. - 2018. - No. 33 (Juni). S. $1-4$.

21. Neues Fähigkeitsprofil komplettiert Konzept zur Modernisierung der Bundeswehr Veröffentlichungs. - Electronic text data. - Mode of access: https://www.bmvg.de/de/aktuelles/neuesfaehigkeitsprofil-der-bundeswehr-27550 (date of access: 25.07.2020). - Title from screen.

22. Norwegian Armed Forces in transition. Strategic Defence Review by the Norwegian minister of Defence. - Oslo : Ministry of Defence, 2015. - 23 p.

23. Panzerdivision. - Electronic text data. - Mode of access: https://www.bundeswehr.de/de/organisation/ heer/organisation/1-panzerdivision (date of access: 25.07.2020). - Title from screen.

24. Ponomareva, E. Quo Vadis, Serbia? / E. Ponomareva // Russia in Global Affairs. - 2020. № 1 (69). - January/March. - P. 158-179. - DOI: 10.31278/1810-6374-2020-18-1-158-179.

25. Rudolf, P. US-Geopolitik und nukleare Abschreckung in der Ära neuer Großmachtrivalitäten / P. Rudolf. - Berlin : Deutsches Institut für Internationale Politik und Sicherheit, 2018. $-28 \mathrm{p}$.

26. The Bundeswehr on Operations: Publication to Mark the $15^{\text {th }}$ Anniversary of the First Parliamentary Mandate for Armed Bundeswehr Missions Abroad. Berlin : Federal Ministry of Defense, 2009. - 120 p.

27. Torkunov, A. Russia and the United States in the evolving world order / eds.: A. Torkunov, N. Noonan, T. Shakleina. - Moscow : MGIMOUniversity, 2018. - 414 p.

28. Trident Juncture: Ein starkes Signal der NATO. - Electronic text data. - Mode of access: https: //www.bundeswehr.de/portal/a/bwde/start/aktuelles/ aus_der_truppe/!ut/p/z1/hY_NCoMwEITfyE1Sat KjIoIQtNT-mUsJJliLTSSk0kMfvpGCN-keBnZm91s
WBFxBGDn 1nfS9NXIIfSPiW8r4kZMdIfzEECp 4yaotQRixDZzh8m9EhBitVIKgVhqawKCrjCq GGgQIpaPWGu1n9dr4PmjnpLcuGq3zw5y8nAt J1CtoEM5STJdT-JPGeZYQSmlWpIcZ-JCTfC-7sp2fhu YujRr03rbJZxifOSvLbfcFcVJpnA!!/dz/d5/L2dBISEvZ0 FBIS9nQSEh/\#Z7_B8LTL2922LU800ILN8O52010O6 (date of access: 25.07.2020). - Title from screen.

29. Truppen-Aufstockung auf 203.000 Mann: Bundeswehr auf der Suche nach neuen Soldaten. Electronic text data. - Mode of access: https:// www.shz.de/deutschland-welt/politik/AufstockungBundeswehr-auf-der-Suche-nach-neuen-Soldatenid21813272.html (date of access: 25.07.2020). - Title from screen.

30. US Military to Send 1,500 More Soldiers to Germany by Late 2020. - Electronic text data. - Mode of access: http://www.voanews.com/a/us-military-tosend-1-500-more-soldiers-to-germany-by-late-2020/ 4561891.html (date of access: 25.07.2020). - Title from screen.

31. Wales Summit Declaration. 5 September 2014. - Electronic text data. - Mode of access: http:// www.nato.int/cps/en/natohq/official_texts_112964.htm (date of access: 25.07.2020). - Title from screen.

32. Warsaw Summit Communiqué. - Electronic text data. - Mode of access: http://www.nato.int/cps/ en/natohq/official_texts_133169.htm (date of access: 25.07.2020). - Title from screen.

33. Weissbuch zur Sicherheitspolitik und zur Zukunft der Bundeswehr. - Berlin : Bundesregierung, 2016. - 143 s.

34. Why Poland wants a permanent US military base, and is willing to pay $\$ 2$ billion for it. - Electronic text data. - Mode of access: https://www.armytimes. com/news/2018/05/29/why-poland-wants-apermanent-us-military-base-and-is-willing-to-pay-2billion-for-it (date of access: 25.07.2020). - Title from screen.

\section{REFERENCES}

1. Danilov D.A. Global'naya strategiya ES: vostochnyj vector [EU Global Strategy: Eastern Direction]. Sovremenaya Evropa [Contemporary Europe], 2017, no. 1 (73), pp. 10-21. DOI: http://dx.doi. org/10.15211/soveurope120171021.

2. Degtyaryov D.A. Ocenka sovremennoj rasstanovki sil na mezhdunarodnoj arene $i$ formirovanie mnogopolyarnogo mira [Assessment of the Current Balance of Power in the International Arena and the Formation of a Multipolar World]. Moscow, RUSAJNS Publ., 2020. 214 p.

3. Aleksandrov M.V., Rodionov O.E., eds. Mirv XXI veke: prognoz razvitiya mezhdunarodnoj obstanovki po stranam $i$ regionam [World in the 
XXI Century: Forecast of the International Situation Development by Countries and Regions]. Moscow, MGIMO-Universitet, 2018. 768 p.

4. Nikitin A.I. Sovremennyy miroporyadok: yego krizis i perspektivy [Modern World Order, Its Crisis and Prospects]. Polis. Politicheskie issledovaniya [Polic. Political Studies], 2018, no. 6, pp. 32-46. DOI: 10.17967/jpps/2018.06.03.

5. Ostankov V.I. Uspeshnoye resheniye problem stroitelstva Vooruzhennich Sil - vazhneisheye usloviye obespechenyia nationalnoyi bezopasnosti [The Successful Solution of the Problems of Building the Armed Forces Is the Most Important Condition for Ensuring National Security]. Baluevskiy Yu.N., ed. Voennya bezopasnost' Rossiskoi Federatsii v XXI veke: sb. nauch. st. [Military Security of the Russian Federation in the XXI Century. Collection of Scientific Articles]. Moscow, TsVSI, 2004, pp. 210-226.

6. Trunov Ph.O. Izmenenie roli FRG v Evrope i mire v realiyah novoj holodnoj vojny: politiko-voennoe izmerenie [Political and Military Aspects of the Changing Role of the FRG in Europe and the World in the Context of the New Cold War]. Aktual'nye problemy Evropy [Current Problems of Europe], 2020, no. 1 (105), pp. 85-109. DOI: 10.31249/ape/2020.01.05.

7. Trunov Ph.O. Rol' Norvegii v voennom planirovanii NATO na sovremennom etape [Norway's Role in NATO Military Planning at the Present Stage]. Evropejskaya bezopasnost': sobytiya, ocenki, prognozy [European Security: Events, Assessments, Forecasts], 2020, no. 56 (72), pp. 20-23.

8. Beer J. Machen 34 Projekte die EU verteidigungsfähig? URL: https://www.faz.net/aktuell/ politik/ausland/pesco-machen-34-projekte-die-euverteidigungsfaehig-16083341.html (accessed 25 May 2020).

9. Briefing Macron's View of the World. The Economist, 2019, November 9, pp. 17-20.

10. Bundeswehr-Pläne: Heer soll drei neue Divisionen bekommen. URL: https://www.dbwv.de/ aktuelle-themen/politik-verband/beitrag/news/ bundeswehr-plaene-heer-soll-drei-volle-divisionenbekommen/ (accessed 25 July 2020).

11. Defence Expenditures of NATO Countries (2011-2018). URL: https://www.nato.int/nato_static fl2014/assets/pdf/pdf_2018_07/20180709_180710-pr201891-en-pdf(accessed 25 July 2020).

12. Division Schnelle Kräfte. URL: https://www. bundeswehr.de/de/organisation/heer/organisation/ division-schnelle-kraefte (accessed 25 July 2020).

13. Einsatzflottille 2. URL: https://www. bundeswehr.de/de/organisation/marine/organisation/ einsatzflottille-2 (accessed 25 July 2020).

14. German Military Strength. URL: https://www. globalfirepower.com/country-military-strength-detail. asp?country_id=germany (accessed 25 July 2020).
15. Gotkowska J. US Marines in Northern Norway. URL: https://www.osw.waw.pl/en/publikacje/ analyses/2018-06-20/us-marines-nothern-norway-0 (accessed 25 July 2020).

16. Joint Press Conference with President Trump and German Chancellor Merkel. URL: https:/ /www.whitehouse.gov/briefings-statements/jointpress-conference-president-trump-germanchancellor-merkel/ (accessed 25 July 2020)

17. Konzeption der Bundeswehr, 2018. Berlin, Bundesministerium der Verteidigung, 2018. 42 p.

18. Major C. Beyond the NATO Summit: Why There Is Long-Term Transatlantic Trouble Ahead. URL: http://atlantic-community.org/beyond-the-natosummit/ (accessed 25 July 2020).

19. Major C. Die Rolle der NATO für Europas Verteidigung. Berlin, Stiftung Wissenschaft und Politik, 2019.42p.

20. Major C. Ein schwieriger Gipfel für die NATO. SWP-Aktuell, 2018, no. 33 (Juni), S. 1-4.

21. Neues Fähigkeitsprofil komplettiert Konzept zur Modernisierung der Bundeswehr Veröffentlichungs. URL: https:/www.bmvg.de/de/aktuelles/neues-faehigkeitsprofilder-bundeswehr-27550 (accessed 25 July2020).

22. Norwegian Armed Forces in Transition. Strategic Defence Review by the Norwegian Minister of Defence. Oslo, Ministry of Defence, 2015.23 p.

23. Panzerdivision. URL: https://www. bundeswehr.de/de/organisation/heer/organisation/1panzerdivision (accessed 25 July 2020).

24. Ponomareva E. Quo Vadis, Serbia? Russia in Global Affairs, 2020, no. 1 (69), January/March, pp. 158179.DOI: 10.31278/1810-6374-2020-18-1-158-179.

25. Rudolf P. US-Geopolitik und nukleare Abschreckung in der Ära neuer Großmachtrivalitäten. Berlin, Deutsches Institut für Internationale Politik und Sicherheit, 2018. 28 p.

26. The Bundeswehr on Operations: Publication to Mark the $15^{\text {th }}$ Anniversary of the First Parliamentary Mandate for Armed Bundeswehr Missions Abroad. Berlin, Federal Ministry of Defense, 2009. 120 p.

27. Torkunov A., Noonan N., Shakleina T., eds. Russia and the United States in the Evolving World Order. Moscow, MGIMO-University, 2018.414 p.

28. Trident Juncture: Ein Starkes Signal der NATO. URL: https://www.bundeswehr.de/portal/a/ bwde/start/aktuelles/aus_der_truppe/!ut/p/z1/ hY_NCoMwEITfyE1S at KjIoIQtNT-mUs JJ1iLTSSk0kMfvp GCN-keBnZm 91 s WBFx BGDn 1nfS9NXIIfSPiW8r4kZMdIfzEECp4 yaotQRixDZzh8m9EhBitVIKgVhqawKCrjCq GGgQIpaPWGu1n9dr4PmjnpLcuGq3zw5y8n AtJ1CtoEM5STJdT-JPGeZYQSmlWpIcZ-JCTfC7sp2fhuYujRr03rbJzxifOSvLbfcFc VJpnA!!/dz/d5/ L2dBISEvZ0FBIS9nQSEh/\#Z7_B8LTL2922 LU800ILN8O52010O6 (accessed 25 July 2020). 
29. Truppen-Aufstockung auf 203.000 Mann: Bundeswehr auf der Suche nach neuen Soldaten. URL: https://www.shz.de/deutschland-welt/politik/ Aufstockung-Bundeswehr-auf-der-Suche-nach-neuenSoldaten-id21813272.html (accessed 25 July 2020).

30. US Military to Send 1,500 More Soldiers to Germany by Late 2020. URL: http://www.voanews. com/a/us-military-to-send-1-500-more-soldiers-togermany-by-late-2020/4561891.html (accessed 25 July 2020).

31. Wales Summit Declaration. 5 September 2014. URL: http://www.nato.int/cps/en/natohq/ official_texts_112964.htm (accessed 25 July 2020).

32. Warsaw Summit Communiqué. URL: http:// www.nato.int/cps/en/natohq/official_texts_133169. htm (accessed 25 July 2020).
33. Weissbuch zur Sicherheitspolitik und zur Zukunft der Bundeswehr. Berlin, Bundesregierung, 2016. $143 \mathrm{~S}$.

34. Why Poland Wants a Permanent US Military Base, and Is Willing to Pay \$2 Billion for It. URL: https://www.armytimes.com/news/2018/05/29/whypoland-wants-a-permanent-us-military-base-and-iswilling-to-pay-2-billion-for-it (accessed 25 July 2020).

33. Weissbuch zur Sicherheitspolitik und zur Zukunft der Bundeswehr. Berlin, Bundesregierung, 2016. $143 \mathrm{~S}$.

34. Why Poland Wants a Permanent US Military Base, and Is Willing to Pay \$2 Billion for It. URL: https://www.armytimes.com/news/2018/05/29/whypoland-wants-a-permanent-us-military-base-and-iswilling-to-pay-2-billion-for-it (accessed 25 July 2020).

\section{Information About the Authors}

Andrey V. Manoilo, Doctor of Sciences (Politics), Professor, Leading Researcher, Institute of Scientific Information on Social Sciences (INION) RAS, Prosp. Nakhimovskiy, 51/21, 117997 Moscow, Russian Federation, cyberhurricane@yandex.ru, https://orcid.org/0000-0002-8142-9110

Elena G. Ponomareva, Doctor of Sciences (Politics), Professor, Department of Comparative Political Science, Moscow State Institute of International Relations (University) of the Ministry of Foreign Relations of the Russian Federation, Prosp. Vernadskogo, 76, 119454 Moscow, Russian Federation, nastya304@mail.ru, https://orcid.org/0000-0001-8370-8597

Philipp O. Trunov, Candidate of Sciences (Politics), Senior Researcher, Institute of Scientific Information on Social Sciences (INION) RAS, Prosp. Nakhimovsky, 51/21, 117997 Moscow, Russian Federation, 1trunov@mail.ru,https://orcid.org/0000-0001-7092-4864

\section{Информация об авторах}

Андрей Викторович Манойло, доктор политических наук, профессор, ведущий научный сотрудник, Институт научной информации по общественным наукам РАН, просп. Нахимовский, 51/21, 117997 г. Москва, Российская Федерация, cyberhurricane@yandex.ru, https://orcid.org/0000-0002-8142-9110

Елена Георгиевна Пономарева, доктор политических наук, профессор кафедры сравнительной политологии, Московский государственный институт международных отношений (университет) МИД Российской Федерации, просп. Вернадского, 76, 119454 г. Москва, Российская Федерация, nastya304@mail.ru, https://orcid.org/0000-0001-8370-8597

Филипп Олегович Трунов, кандидат политических наук, старший научный сотрудник, Институт научной информации по общественным наукам РАН, просп. Нахимовский, 51/21, 117997 г. Москва, Российская Федерация, 1trunov@mail.ru, https://orcid.org/0000-0001-7092-4864 